\title{
Students' perspectives on technology integration in ELT
}

\author{
Renu Singh \\ Tribhuvan University, Nepal
}

\begin{abstract}
Technology integration in English language teaching (ELT) has changed the mode of classroom instruction at school. The use of modern technologies at public secondary schools within Nepal is a big challenge.This study explores students' perspectives on technology integration in English language teaching at public secondary schools in Nepal. The study was framed under qualitative research design that used focus group discussion to gather data from the six groups of students in the Kathmandu valley. The thematic analysis of their views under different categories revealed that the ELT with technology integration is a dire need for developing students' language proficiency. Additionally, the results show that the learners of English as a foreign language (EFL) are aware of the advantages of teaching with technology but the insufficient ICT infrastructure at school and the lack of EFL teachers' professional skills and knowledge of integrating technology into their daily pedagogical practices are main obstacles of technology integration. The study points out implications for ELT practitioners, researchers, policy makers of ICT in education along with stakeholders.
\end{abstract}

Key words: ELT, EFL, technology integration, CALL, professional development, TPACK, Constructivism

\section{Introduction}

ELT has undergone many pedagogical changes. The earliest widely used 'Grammar-Translation Method' was focused on imparting the knowledge of the English grammar to enable students interpret literary texts and write the appreciation of them with the correct usage of the English language. Even though, it has bundles of weakness, it is still in practice at schools with multilingual students. Many other methods such as Direct method, Audiolingual method, Oral Structural and Situational approach, Communicative language teaching (CLT) etc. came into practice with the hope of bridging the gap of the previous methods in ELT. Moreover, the integration of innovative technology into ELT pedagogy in particular is supposed to bring some 
substantial changes. Similarly, it is now a mandatory to integrate ICT tools in school education (Ministry of Education, 2013).

It is not new for teachers to incorporate technology in their pedagogy at public secondary schools in Nepal. There is a long history of using old/traditional technology tools such as audio, video, projector, slides, tape-recorder, radio, $\mathrm{TV}$, telephone and so on. The inclusion of new innovative technology tools such as laptop, smart board (interactive whiteboard), LCD projector, smart phone, multimedia, the Internet and social networking sites (SNSs) in the educational settings (Salehi \& Salehi, 2011) has transformed the mode of constructing knowledge. Moreover, teachers and students get access to information along with opportunities to participate and contribute to the knowledge economy by the use of technology (United Nations Group on the Information Society, 2013, as cited in UNESCO, 2015).

Though there are some studies (Blachowicz et al., 2009; Yuksel \& Tanriverdi, 2009; Tilfarlioglu, 2011) carried out outside Nepal on students' perception and attitude towards technology integrated instruction, there is very limited number of studies conducted in Nepal. Thus, this study adds to bridge up the existing gap.

The present study aims at exploring the students' perspectives of technology integrated EFL instruction and possible barriers to it. The following research questions were designed to frame the study under qualitative research approach;

a) What are the students' experiences of technology integrated EFL instruction?

b) What are the barriers to technology integrated EFL instruction?

\section{Review of literature}

\section{English language teaching with technology}

The present phenomenal change in the trends of teaching English has primarily focused on developing the language skills of learners with the help of modern technological tools such as hard-wares, soft-wares, the Internet, and mobile technologies. Technology integrated instruction is primarily based on the theories of learning and Second Language Acquisition (SLA) in which individualization, interaction and motivation are considered to be paramount in the learning process (Mullamaa, 2010). Furthermore, Mullamaa (2010) justifies his finding in the light of the relationship discussed between student motivation and elearning.

Technology integration into language teaching and learning is generally referred to as computer aided or computer assisted language learning (CALL). Moreover, CALL technology in ELT, in particular computer mediated communication, promotes students' communicative competence through 
interactive speaking practicesinside and outside the classroom (Warschaur, 1998). Additionally, CALL is very effective for practicing any aspects of language: grammar, vocabulary and pronunciation, and any skills of language: listening, speaking, reading and writing. It promotes student-centered language learning in that students could learn at their own pace and develop the habit of autonomous learning (Gonglewski, 2003). Similarly, CALL in the EFL writing classroom creates a supportive and motivating environment for learners to work at their own pace along with the level of their linguistic developmental. Additionally, it promotes their independent writing skills and creativity (Fidaoui, Bahous, \& Bacha, 2010).

Conversely, there are several factors found to be influencing technology integration in teaching in schools. The factors such as teachers' knowledge and skill of technology integrated instruction, teachers' perception, attitude towards technology, work load and time, support from school administration, availability of technology infrastructure at school, syllabus and curriculum influence use of technology in education (Boakye and Banin, 2008; Chen, 2008).

\section{Students' perception of technology integrated teaching}

Blachowicz et al. (2009) observeed students' and teachers' perceptions and beliefs for the use of technology. They designed a computer assisted literacy program to instruct reading skill to the students. They revealed that the students were highly engaged in doing the literacy tasks independently and confidently.
Further, they concluded that teaching/ learning with technology allow teachers sufficient time for additional activities. Yuksel and Tanriverdi (2009) explored the effects of captioned movie clips on the vocabulary development of EFL learners. The findings showed that the demonstration of captioned movie clips helped students acquire vocabulary effectively and facilitated their reading comprehension too.

Tilfarlioglu (2011) conducted a research study to determine undergraduate and high school students' attitudes towards the use of English in Web 2.0 technology. The quantitative research approach of the study randomly selected 534 students from 6 different universities and 3 high schools in Turkey and Iraq to participate. It revealed that the students were highly positive towards the use of Web 2.0 technologies that were found to be a very effective learning tool to practice language in a real like situation.

\section{Teachers' skills and knowledge of ICT integration}

'Technology integration is a complex and multidimensional process' (Demir, 2011, p.75) that requires teachers to be skilled and competent in designing technology integrated lessons and strategies of implementation for effective instructional practices. In Nepal, integrating technology into teaching and learning is one of the burning challenges teachers in public secondary schools face. Though the teachers are highly positive, the actual usage of technology in class is very low (Thapaliya, 2014). Teachers require to be trained on how to integrate technology into teaching and learning 
processes (Sáncheza, Marcosb, Gonzáleza, \& GuanLina, 2012).

Thapaliya (2014) focused on exploring teachers' perceptions and practices of information and communication technologies (ICTs) in teaching English in public schools in Nepal. He found that the most widely used ICT tools were audio tape, mobile phone, computer, television, radio, video tape and email. It was also revealed that though the secondary level English teachers had positive attitudes towards the use of ICTs, insufficient class time and inadequate training opportunities were the major hindrances to ICT integration in ELT. Further, he recommended the need of technical and pedagogical training of ICTs for secondary level English teachers

The effective integration of technology into pedagogy basically lies in the teachers' beliefs or motivation (Ward \& Parr, 2010). Their motivation to go with technology will certainly be a very crucial turning point to their professionalism. Moreover, their beliefs and motivation should be sustained through professional development trainings and supports for innovative technology (McGill, Klobas \& Renzi, 2014) to facilitate students' learning in technology-rich academic environment through their expertise. It is teachers' expertise that makes them feel more confident and innovative to incorporate technology resources or tools into the tasks and contents to be delivered (Ramierez, Clements \& Canedo, 2012). Professional development trainings keep teachers up-to-date and adaptive to the most effective use of emerging technologies for teaching and learning (Lawless \& Pellegrino, 2007). Additionally, these trainings specifically need to be based on research and implementation strategies that may ensure the teachers' competencies in teaching with technology diffusion (Blin \& Munro, 2008).

'Technological Pedagogical and Content Knowledge (TPACK) framework has been used for teacher development in different areas and at different levels. It is the knowledge of how the teacher uses the technology related to a specific area to enhance students' understanding' (Demir, 2011, p.81). The underlying assumption of TPACK framework is that teachers learn technology integration by doing, which is called learningtechnology-bydesign approach (Mishra and Kohler 2006). Thus, in order to support EFL teachers' skills and knowledge of ICT in teaching, TPACK framework will be crucial.

\section{Theoretical perspective}

Constructivism is a set of theories that was developed in the 1970s with the pioneering contributions of the theorists Jean Piaget (1896-1980) and Lev Semyonovich Vygotsky (1896-1934). It combines two approaches of learning; philosophical and psychological and believes that interaction happens in a reciprocal way with persons' behaviors and environments (Schunk, 2000). Furthermore, constructivists advocate in favour of integrating technologies for effective teaching and learning (Duffy \& Cunningham, 1996). Jonassen, Peck, and Wilson (1999) take technology as "the designs and environments that engage learners" (p. 12). Similarly, constructivists refer to technologies as 
cognitive tools that "engage the learners more and result in more meaningful and transferable knowledge... Learners function as designers using the technology as tools for analysing the world, accessing information, interpreting and organizing their personal knowledge, and representing what they know to others" (Jonassen, 1994, p. 2). Thus, technology and constructivism together are focused on creating such a learning environment that could mediate learners for the construction of knowledge.

The theoretical perspective of constructivism is highly applicable to the study. Thus, the conceptual framework of the study is based on the assumption that technology has potential to engage learners for knowledge creation that would be cross-checked through exploring the students' perspectives of technology integrated EFL instruction.

\section{Methodology}

The study employed purposeful sampling procedure to select the research participants from the public secondary schools of the Kathmandu valley that included three districts: Kathmandu, Bhaktapur and Lalitpur. Six public secondary schools were also selected using the purposive judgmental sampling procedure on the basis of availability of modern technology tools (ICT infrastructure), and the Internet connectivity. Hence, the schools were found to have SMART board, computers, laptop, projector, white board, Bluetooth, sound systems, Wi-Fi connection and so on. Moreover, some schools also had power backup facility.
The study used focus group discussion as a research tool to collect the required data from the six groups of students. The reason behind choosing the focus group discussion was to dig deeper into the students' perspectives of technology integrated instruction in EFL. It was supposed that they could express better in group being motivated listening to others' views than in the individual interview. Further, the discussion was framed under three specific themes to achieve the research objectives; Technology integrated EFL teaching, teachers' skills and knowledge of technology integration in EFL teaching, and obstacles of technology integrated instruction. Hence, altogether, eight open-ended questions were used for the discussion and it was 40/45 minutes long. There were 10/11 students including boys and girls in each group studying in the $10^{\text {th }}$ grade. The discussion was held with all the six groups of students at different dates at their respective schools.

The researcher visited the chosen public secondary schools to get the permission from the headmasters. After getting the consent, the six focus groups were formed for discussion.

\section{Participants and procedures}

The six purposefully composed focus groups of students were given pseudonyms and the groups were also named A, B, C, D, E and F to assure the research ethics and the confidentiality of the research participants. Moreover, they were recruited in terms of a number of factors; gender, school location and categories, and classroom instruction with technology integration. The 
participants were also assured of the confidentiality of their views expressed during the discussion that would not be used other than the research purpose.

\section{Data analysis and interpretation}

The six different focus groups of students were told about the purpose of the discussion. The discussion was conducted at their schools at different times. The groups were assigned codes as A, B, C, D, E and F. As there were 10 to 11 participants in each group, they all were recognized by the code given to their respective groups. Each group discussion was started with the background of technology integration in EFL.The discussion data were digitally recorded on an audio device. As the participants were said to express their views either in English or Nepali. Thus, the participants' views expressed into the Nepali language were transcribed into English. After that all the data were converted into the textual form for analysis. Further, the data were analysed thematically to develop the themes and categories. The following themes were generated for the further interpretation:

1. EFL teaching with technology integration

2. EFL teachers' skills and knowledge of technology integrated teaching

3. Obstacles of technology integrated instruction

\section{Findings and discussion}

The results of the three thematic categories were analysed and discussed in the theoretical light of constructivism that advocates for integrating technology tools for learner-cantered pedagogy (Duffy \& Cunningham, 1996). Further, it believes that technology integrated instruction makes students highly engaged to accelerate independent learning in which the role of teacher is of a guide or facilitator.

\section{EFL teaching with technology integration}

All six groups of students were found to be taught EFL by integrating technology. They revealed that technology integration in teaching English lessons aroused their interest, held their attention to focus on the lesson. Further, they said that the use of multimedia made the lesson very interesting through colourful visuals and audio. Their views were in favor of technology integration for effective teaching and learning of EFL. Some of their views are presented below:

\section{A participant from group ' $A$ '}

... makes us learn through experiment practically that is our capacity. In ICT lab, we learn through visualization that sticks to our mind ...(translated version)

\section{A participant from same group stated that:}

Not every pupil can learn by reading or studying. There're various types of pupils. The pupils have various ways of learning. Therefore, some pupils need audio, learning, some pupils need learning by seeing and some pupils can learn by reading 
only therefore, every type of pupils can get their need by using ICT tools.

\section{A participant, group ' $B$ '}

It's very comfortable to understand when we see videos, we understand all. When we hesitate to ask questions to teachers, videos make it clear to us to understand all. We can learn everything well through ICT tools.

\section{Similar view from the same group}

Learning through ICT will be very good. We can easily understand whatever is taught through the help of ICT. When ... teacher teach us through the books then we can't be understanding and we feel like laziness. Obviously, when teacher tell us come ... and let's watch through the videos then we feel like exciting, more exciting and sometimes we forget like something else written in the book, can be visualized we can remember through what we've seen so I think ICT has been great influence in students' life if our books are teaching through the help of ICT.

\section{A Participant, group 'C'}

I think ICT would be like perfect for learning. It improves both the quality of teaching and learning process. Seeing same teacher in the class all the year, it is somehow very monotonous for me. But when I see some videos I feel so excited and curious about the subject ... I don't know how but I feel so (she was very excited in her expression) like I understood all the things but when teacher speaks I feel like at first I'm energetic, oh Yeah! Yeah!! ... I just feel monotonous and but if he or she, the teacher uses ICT tools then my excitement goes through all the year

\section{A participant, group 'C'}

Actually when there's use of multimedia and ICT then the students will be more curious to know and they will be paying their full attention to focus on the particularly topic and they can catch many more ideas regarding the topic which all the teachers can't deliver in the classroom.

\section{A participant, group ' $C$ '}

... it broadens our creativity and brings vision, that's it.

\section{A participant, group ' $D$ '}

I also feel more motivated in SMART class than in general class because if ICT tools are used in teaching English, students could understand fast. We could find specific meanings of a word, understand clearly and get clear concept. Visuals make us learn specifically. (translated version)

Another participant from the same group

It's easy for me to get taught trough ICT tools. ICT facilitates learning, activates right brain that makes learning faster. (translated version) 


\section{A participant, group ' $E$ '}

In normal classroom setting, our attention goes somewhere but in ICT lab our attention gets focused on the lesson due to videos ... in SMART class we could get varieties of style of teaching the same topic ... that helps us understand more. (translated version)

\section{A participant, group ' $F$ '}

While a poem is taught in SMART class, the stanza wise meaning is very clear, seems very easy to understand there. (translated version)

\section{EFL teachers' skills and knowledge of technology integrated teaching EFL}

The participants of the focus groups highly emphasized the need of EFL teachers' skills and knowledge of technology integration. They revealed that their EFL teachers could manage to integrate ICT tools in teaching English but that were limited to the basic usage of technology tools i.e. YouTube, Google searching, and power-point presentation for EFL lessons. They also said that their EFL teachers were highly in need of technology integration training for its effective application in instruction. Their views are presented below:

A participant from group 'A' expressed that:

... for now talking about our English teacher, she is well trained. She has just been to Korea for this same topic training so she is well trained to use ICT. In general, some teachers need more training to use technology.

\section{Participants from the same group}

If teachers have good practice, it would be easy for us, too. Teachers should practice in the best way after getting the training. ICT is complicated too as it has many devices therefore, they need training to use ICT that lacks in our teachers. They should take training for best practice in teaching. (translated version)

There's a lack of manpower in ICT. Many teachers are in habit of teaching by writing on the board. If all teachers participate in using ICT, the future of all countries would be good.(translated version, group ' $A$ ')

A participant from group ' $B$ ' expressed that:

They need more training. That is not sufficient. Teachers don't know much about technology. They have only limited skills and knowledge of technology therefore, students also see and learn in limit. The teachers could have done better than it, more attractive than it as I felt. The teachers need more training.

Other group's participants also thought that the teachers 'are not getting training', ' government should manage training for teachers' and '... ICT is changing technologies so the knowledge they get at one stage may not be useful at the next time because it brings some changing so they must get knowledge and skills of particular technology as it changes time and again so I guess they're not too much skilled ... so they need some trainings according to these 
upgraded technology'. Similarly, Groups E and F some teachers are 'well trained in using YouTube, Google, etc. for searching videos and other materials related to our course. They teach us through videos on SMART board and also use powerpoint software for presentation of poems (group E) but they should 'have some more skills and knowledge of technology.The students expressed the need of advance ICT training for their EFL teachers as they were limited to basic usage of modern technology tools (Sáncheza, Marcosb, Gonzáleza, \& Guan Lina, 2012) available at school ICT lab. They mentioned that if their EFL teachers could use technology with variations for teaching English, the students' ability to utilize those technology tools will certainly increase.

\section{Obstacles of technology integrated instruction}

During the discussions, the participants expressed their views regarding the obstacles of technology integrated instruction. Those were related to teachers' technology integration knowledge and skills in teaching EFL, frequency of technology integrated EFL class, insufficient ICT infrastructure at school, and digital divide i.e. majority of the students of public schools were from low economy family that could not afford them technology access at home. They expressed that:

The participants expressed their views that the teachers needed sufficient skills and knowledge to integrate technology in the classroom instruction (Ramierez,
Clements \& Canedo, 2012). The technology integration skills and knowledge which they had, were limited to basic usage of technology tools and soft-wares like YouTube, Google search, power point presentation, and word office.

\section{Frequency of technology integration in EFL class}

Modern technology tools could facilitate their learning under the teachers' guidance. In this context, frequent technology integrated instruction not only could arise their interest but also could make them more creative and constructive into their learning approaches. The frequency of technology integration which they got, was found limited to once or twice a week

\section{The participants expressed the view that:}

'I don't think once a week is sufficient for us (A)'technology integration needs to be more frequent than once a week. We've ICT lab but it's not properly utilized' (B), 'our principal encourages but teachersdon't. They don't use technology frequently because they don't know how to use technology (C).

\section{Insufficient ICT infrastructure at school and the digital divide}

During the discussion, the participants expressed their view that though the schools had SMART board, projector, computers, laptop, sound system, Bluetooth, and the Internet connectivity but the devices were not sufficient for all the students to get frequent technology integrated classes. A single 
ICT lab with limited tools and many classes except the EFL class are certainly a big challenge for public secondary schools to increase frequency and maximum exposure of technology integration in teaching EFL. Additionally, at public schools in Nepal the students mostly come from lower income families, and therefore, they could not afford modern technology tools for their children at home. Thus, most students are deprived of such practice. Consequently, either they need to go to their friends' home who have the ICT tools or go to cyber-cafes to do assignments given by their EFL teachers. Thus, the digital divide has held them back in comparison to their fellow students in terms of creativity and construction of knowledge.

The participants' expressed the following views during the focus group discussion:

'Many elements are needed for ICT e. g. visual, animation and graphic, sound, audio, for these elements different devices are available on ICT which aren't available in the class' ...'We go to our friends' home to do the project work in group or may go to cyber that costs 20 Rupees per hour. Our parents don't allow us to go to cyber frequently'(A), 'these technology tools aren't sufficient for us because we're 45/50 students in each class ....'school should provide ICT tools to those students who don't have these tools at home or even can't afford to go to cyber' .. or allow students to use computer lab after school' (D) and there is parental disbelief in students thinking that they might misuse the technology if they leave on their own. (E \& F).
The participants of all the six groups exposed that their EFL teachers' lacked the required skills and knowledge of technology integration in teaching and learning. Similarly, more than average students did not have ICT tools at their home so that their teachers rarely gave them project work to get proficiency in the English language. The problem with going to cyber was that their parents did not allow to go there due to the fear of misusing the Internet and the students also accepted that many students wasted their time playing games in cyber instead of doing assignments given by their EFL teachers.

\section{Conclusion}

This study employed a qualitative research design to explore the students' perspectives of technology integration in teaching/learning EFL at public secondary schools in Nepal. The data collected through the 6 focus group discussionson students' perspectives on technology integration in EFL class revealed that they got highly motivated and attentive in learning because modern technology tools with multimedia affect could hold their attention during the classroom instruction. However, their EFL teachers' limited skills and knowledge of ICT integration could not utilize well the educative potentials of those tools. They simply used some soft-wares such as YouTube, Google search and powerpoint presentation in terms of technology integration. Thus, their EFL teachers were highly in need of profession trainings to be updated for technology integrated instruction. The TPACK framework proposed by Mishra and Kohelar (2006) may guide teachers for 
effective integration technology in pedagogy. Additionally, there were some other obstacles such as insufficient ICT infrastructure at school, limited frequency of technology integrated EFL class and digital divide were found to hinder effective integration of technology tools in teaching/learning EFL.

The study is expected to contribute to an understanding of public secondary school students' perspectives on technology integrated EFL instruction. This adds to the ongoing deliberations and conversation in the existing literature. Moreover, the study recommends for further in-depth studies in the areas: students' perceptions and usage of technology in learning EFL, school leadership in technology integration, digital divide and technology integration, and models of professional training for teachers to integrate technology.

\section{References}

Blachowicz, C., Bates, A., Berne, J., Bridgman, T., Chaney, J., \& Perney, J. (2009). Technology and at-risk young readers and their classrooms. Reading Psychology, 30(5), 387-411. http:// d x.d o i . o r g / $10.1080 /$ 02702710902733576.

Boakye, K. B. \&Banini, D. A. (2008). Teacher ICT readiness in Ghana. In K. Toure, T.M.S.

Chen, C.H (2008). Why do teachers not practice what they believe regarding technology integration? Journal of Educational Research, 102, (1) 65 - 75.

Demir, S. (2011). Two Inseparable Facets of Technology Integration Programs: Technology and Theoretical Framework. Eurasia Journal of
Mathematics, Science \& Technology Education, 7(2), 75-88.

Duffy, T. M., \& Cunningham, D. J. (1996). Constructivism: Implications for the design and delivery of instruction. In D. H. Jonassen (Ed.), Educational communications and technology (170199). New York: Simon \& Schuster Macmillan.

Fidaoui, D., Bahous, R., \&Bacha, N. N. (2010). CALL in Lebanese elementary ESL writing classrooms. Computer Assisted Language Learning, 23(2), 151168. http://dx.doi.org/10.1080/ 09588221003666248

Gonglewski; Meloni\& Brandt (2003). Advantages and disadvantages of using computer network technology in language teaching. In Huynh ThiBich Ngoc (2005). http:// www.englishtime.us/learningenglish/ Lear ningEnglish.aspx

Jonassen, D. H. (1994). Technology as cognitive tools: Learners as designers. Retrieved 20/12/2018, from http:/ / itech1.coe.uga.edu/itforum/paper1/ paper1.html

Jonassen, D. H., Peck, K. L., \& Wilson, B. G. (1999). Learning with technology: A constructivist perspective. Upper Saddle River, NJ: Merrill/Prentice Hall.

Ministry of Education. (2013). Information and communication technology (ICT) in education: Master plan 2013-2017. Kathmandu, Nepal: Author.

Mishra, P., \& Kohler, M. J. (2006). Technological pedagogical content knowledge: A framework for teacher knowledge. Teachers College Record, 8(6), 1017-1054.

Mullamaa, K. (2010). ICT in language learning: Benefits and methodological implications. International Education Studies, 3(1), 38-44. 
Salehi, H., \& Salehi, Z. (2011). Integration of ICT in language teaching: Challenges and barriers. Proceedings of the $3 \mathrm{rd}$ International Conference on e-Education, $e$-Business, e-Management and $e$ Learning(IC4E, 2012). IPEDR, 27, 215219.

Sáncheza, A., Marcosb, J.M., Gonzáleza, M. \&GuanLina, H. (2012). In-service teachers' attitudes towards the use of ICT in the classroom. Procedia - Social and Behavioral Sciences, 46:1358-1364.

Schunk, D. H. (2000). Learning theories: an educational perspective. New Jersey: Prentice-Hall.

Thapaliya, M. P. (2014). English Teachers' perceptions and practices of Information and Communication Technologies (ICTs) in Kathmandu District. Nepal. Academic Research Journals, 2(10), 251-258. http:// www.academicresearchjournals.org/ IJARER/Index.htmDOI: 10.14662/ IJARER2014.05

Tilfarlioglu, F. Y. (2011). An International Dimension of the Student's Attitudes towards the Use of English in Web 2.0 Technology. Turkish Online Journal of Educational Technology-TOJET, 10(3), 63-68.

Tapscott, D. (1998). Growing up digital: the rise of the Net generation. New York: McGraw-Hill.

UNESCO. (2015a). Fostering digital citizenship through safe and responsible use of ICT: A review of current status in Asia and the Pacific as of December 2014. Bangkok, Thailand: Author.

Warschauer, M. \& Healey, D. (1998). Computers and language learning: An overview. Language Teaching, 31, 57-71.

Yuksel, D., \& Tanriverdi, B. (2009). Effects of watching captioned movie clip on vocabulary development of EFL learners. The Turkish Online Journal of Educational Technology, 8(2), 33-47.

Yunus, M. (2007). Malaysian ESL teachers' use of ICT in their classrooms: expectations and realities. RECALL: The Journal of EUROCALL, 9 (1): 79-95.

Contributor: Renu Singh is a lecturer in English Education at Thakur Ram Multiple Campus, Birgunj, Tribhuvan University. She has been teaching at the campus for the last 20 years. Currently, she is a Ph.D. scholar under Norhed Quantic Project, Faculty of Education, Tribhuvan University, Kathmandu. She has published journal articles and co-authored a textbook on Academic Writing. Her research area is ICT integration in teaching English at School. 